\title{
Comparison of Application Methods of Paclobutrazol for Height Control of Pot ted Tulips
}

\section{Frederick Deneke ${ }^{1}$ and Gary J. Keever ${ }^{2}$ \\ Department of Horticulture, Alabama Agricultural Experiment Station, Auburn University, AL 36849-5408}

\begin{abstract}
Additional index words. plant growth retardant, plant growth regulator, ancymidol, flowering potted plant, Tulipa gesneriana
\end{abstract}

Potted tulips (Tulipa gesneriana L.) often become excessively tall either during greenhouse production or in postproduction environments. Therefore, plant growth retardants are commonly used to control plant height and reduce stem topple (De Hertogh, 1989). Drench application of $0.5 \mathrm{mg}$ ancymidol/15$\mathrm{cm}$ (top diameters) pot restricted height of 'Paul Richter' tulips by $\approx 25 \%$ when compared with that of nontreated plants if the application was made during the first 6 days after forcing began in the greenhouse (Shoub and De Hertogh, 1974). De Hertogh (1989) suggested a drench of 0.25 to $0.50 \mathrm{mg}$ ancymidol/10- or $15-\mathrm{cm}$ pot for 'Kees Nelis' tulips. Drench application of 0.25 or 0.50 $\mathrm{mg}$ paclobutrazol $/ 15-\mathrm{cm}$ pot was as effective as 0.50 or $0.75 \mathrm{mg}$ ancymidol $/ 15-\mathrm{cm}$ pot in restricting height of 'Paul Richter' tulips (McDaniel, 1990).

Foliar sprays and drenches are the most common methods of application of plant growth regulators (Larson, 1985). However, to reduce application costs and improve the effectiveness of growth regulators, alternative application methods have been investigated (Einert, 1976; Read et al., 1974; Sanderson et al., 1988; Wilfret et al., 1978). The objective of this study was to investigate the effectiveness of paclobutrazol applied as a drench or impregnated in a fertilizer spike for height control of tulips.

On 21 Dec. 1987, five bulbs ( $\geq 12 \mathrm{~cm}$ in circumference) of 'Kees Nelis' tulips were potted per 0.8 -liter $(12.7 \mathrm{~cm}$ in diameter $)$ container using a commercial peatmoss and perlite growing medium (Pro Mix BX, Premier Brands, Stamford, Conn.) and placed in darkness at 9C. On 20 Jan. 1988, when root growth out of the bottom of the pot was evident, temperature was increased to $5 \mathrm{C}$ until the emerging shoots were $\approx 4 \mathrm{~cm}$ long (De Hertogh, 1989). Plants were moved to a

Received for publication 26 Mar. 1992. Accepted for publication 8 July 1992. Alabama Agricultural Expt. Sta. no. 11-923281. Technical assistance of Cathy Browne is gratefully appreciated. Mention of a trademark, proprietary product, or vendor does not imply endorsement by Auburn Univ., nor criticism of similar ones not mentioned. The cost of publishing this paper was defrayed in part by the payment of page charges. Under postal regulations, this paper therefore must be hereby marked advertisement solely to indicate this fact.

'Assistant Professor of Horticulture.

${ }^{2}$ Associate Professor of Horticulture. double-layer polyethylene greenhouse maintained at $18 \mathrm{C}$ day (ventilation setpoint) and 14C night (heat setpoint). The foliowing treatments were applied 1 day after the plants were moved: drench or spike of $0,0.06$, 0.25 , or $1.00 \mathrm{mg}$ paclobutrazol/pot; or drench of $0.25 \mathrm{mg}$ ancymidol/pot. Drenches were applied using a volume of $75 \mathrm{ml} /$ pot. Spikes were identical to Jobe Fertilizer Spikes (10N4.3P-3.3K, Weatherly Consumer Products, Lexington, Ky.), except that the manufacturer incorporated paclobutrazol; the composition of the spike is confidential to the manufacturer. One spike was positioned vertically just below the surface of the growing medium in the center of a pot. Five pots per treatment were arranged in a completely randomized design.

Plants were fertilized weekly, alternating $200 \mathrm{mg}$ N/liter 20N-8.7P-16.6K and 375 mg N/liter $\mathrm{Ca}\left(\mathrm{NO}_{3}\right)_{2}$. When flowers first showed color, plant heights were measured. When flowers were fully opened, plant heights

Table 1. Height of 'Kees Nelis' tulips treated with an ancymidol drench or increasing rates of paclobutrazol applied as a drench or an impregnated spike.

\begin{tabular}{lcc}
\hline \multirow{2}{*}{$\begin{array}{l}\text { PGR } \\
\text { application method }\end{array}$} & \multicolumn{2}{c}{ Plant ht (cm) at } \\
\cline { 2 - 3 } & Flower color & Maturity \\
\hline \multirow{3}{*}{ Paclobutrazol $(\mathrm{mg} /$ pot $)$} \\
0.06 & 23.0 & \\
0.25 & 20.6 & 29.0 \\
1.00 & 16.2 & 24.4 \\
Spike & & \\
0.06 & 21.8 & 26.7 \\
0.25 & 20.1 & 24.6 \\
1.00 & 19.1 & 24.0 \\
Significance of rate & & \\
Drench & $\mathrm{L}^{* *}$ & $\mathrm{~L}^{* *}$ \\
Spike & $\mathrm{L}^{*}$ & $\mathrm{~L}^{*}$ \\
Contrasts & & \\
Drench vs. spike & $\mathrm{NS}$ & $\mathrm{NS}$ \\
& Ancymidol & $(0.25 \mathrm{mg} /$ pot $)$ \\
Drench & 19.2 & 23.8 \\
Control & 21.7 & 27.7 \\
Dunnett'sw & 2.2 & 2.8 \\
\hline
\end{tabular}

${ }^{2}$ Plant growth regulator.

yWhen flowers were fully opened.

*Single-degree-of-freedom contrasts were not significant, $P=0.05$.

wUsed to compare ancymidol-treated plants with

*,** Significant linear response at $P=0.05$ or 0.01 , respectively; control used in regression analysis. other treatments, $P=0.05$. and flower diameters were measured. Rate response to paclobutrazol was determined by regression analysis. Single-degree-of-freedom contrasts were used to compare application methods. Dunnett's test was used to compare ancymidol-treated plants with other plants.

Time to maturity (time from entering the greenhouse to flowers fully opened) for 'Kees Nelis' tulips was $\approx 21$ days regardless of treatment. McDaniel (1990) reported that time to colored bud stage for 'Paul Richter' tulips increased as drench application rate of paclobutrazol increased from 0.25 to $1.00 \mathrm{mg} /$ pot.

Heights at first flower color and at maturity were reduced linearly as the concentration of paclobutrazol increased with both application methods (Table 1). Method of application of paclobutrazol did not significantly affect any of the measured variables. Treatments had no effect on flower diameter; McDaniel (1990) similarly determined that flower size of 'Paul Richter' tulips was not affected by ancymidol or paclobutrazol. Uniformity of plants within a pot was similar regardless of treatment.

Ancymidol-treated plants at first flower color and at maturity were shorter than those that had received the lowest rate of paclobutrazol applied as a drench or spike, or than control plants.

Because potted plants should be no taller than two times the diameter of the pot (Beattie, 1982), the maximum acceptable height for plants in a 12.7 -cm-diameter pot is 25.4 $\mathrm{cm}$. Therefore, plants receiving a spike or drench of 0.25 or $1.00 \mathrm{mg}$ paclobutrazol/pot or a drench of $0.25 \mathrm{mg}$ ancymidol/pot had acceptable heights at maturity. In contrast, control plants were $27.7 \mathrm{~cm}$ tall at maturity.

\section{Literature Cited}

Beattie, D.J. 1982. Minimum attention helps popularity of herbaceous perennial pot plants. Florists Rev. 171(4424):66, 71-72, 74.

De Hertogh, A. 1989. Holland bulb forcer's guide. 4th ed. Intl. Flower-Bulb Centre, Hillegom, The Netherlands.

Einert, A.E. 1976. Slow-release aneymidol for poinsettia by impregnation of clay pots. HortScience 11:374-375.

Larson, R.A. 1985. Growth regulators in floriculture, p. 399-481. In: J. Janick (ed.). Horticultural review. vol. 7. AVI, Westport, Conn. McDaniel, G.L. 1990. Postharvest height suppression of potted tulips with paclobutrazol. HortScience 25:212-214.

Read, R.E., V.L. Herman, and D.A. Heng. 1974. Slow-release chlormequat: A new concept in plant growth regulators. HortScience 9:55-57.

Sanderson, K.C., W.C. Martin, Jr., and J. McGuire. 1988. Comparison of paclobutrazol tablets, drenches, gels, capsules, and sprays on chrysanthemum growth. HortScience 23:10081009.

Shoub, J. and A.A. De Hertogh. 1974. Effects of ancymidol and gibberellins $\mathrm{A}_{3}$ and $\mathrm{A}_{4+7}$ on $T u$ lipa gesneriana L. cv. Paul Richter during development in the greenhouse. Scientia Hort. 2:55-67.

Wilfret, G.J., B.K. Harbaugh, and T.A. Nell. 1978. Height control of pixie poinsettia with a granular formulation of ancymidol. HortScience 13:701-702. 